\title{
Hybrid Electric Vehicle Fleet And Baseline Performance Testing
}

\section{SAE 2006 World Congress}

\author{
James Francfort \\ Don Karner \\ Ryan Harkins \\ Joseph Tardiolo
}

\section{April 2006}

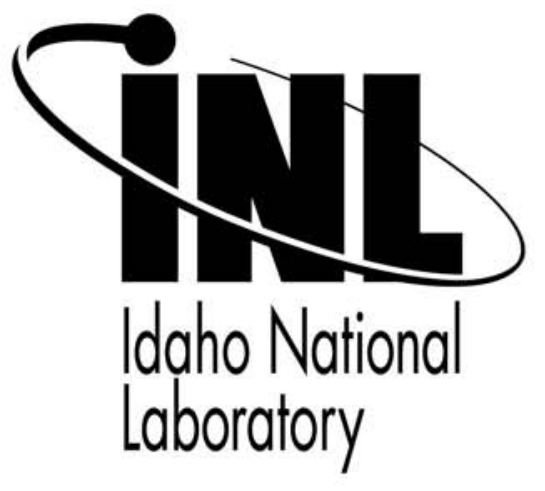

This is a preprint of a paper intended for publication in a journal or proceedings. Since changes may not be made before publication, this preprint should not be cited or reproduced without permission of the author. This document was prepared as an account of work sponsored by an agency of the United States Government. Neither the United States Government nor any agency thereof, or any of their employees, makes any warranty, expressed or implied, or assumes any legal liability or responsibility for any third party's use, or the results of such use, of any information, apparatus, product or process disclosed in this report, or represents that its use by such third party would not infringe privately owned rights. The views expressed in this paper are not necessarily those of the United States Government or the sponsoring agency. 


\title{
Hybrid Electric Vehicle Fleet and Baseline Performance Testing
}

\author{
James Francfort \\ Idaho National Laboratory \\ Don Karner and Ryan Harkins \\ Electric Transportation Applications \\ Joseph Tardiolo \\ Exponent Failure Analysis Associates
}

\begin{abstract}
The U.S. Department of Energy's Advanced Vehicle Testing Activity (AVTA) conducts baseline performance and fleet testing of hybrid electric vehicles (HEV). To date, the AVTA has completed baseline performance testing on seven HEV models and accumulated 1.4 million fleet testing miles on $26 \mathrm{HEVs}$. The HEV models tested or in testing include: Toyota Gen I and Gen II Prius, and Highlander; Honda Insight, Civic and Accord; Chevrolet Silverado; Ford Escape; and Lexus RX 400h. The baseline performance testing includes dynamometer and closed track testing to document the HEV's fuel economy (SAE J1634) and performance in a controlled environment. During fleet testing, two of each HEV model are driven to 160,000 miles per vehicle within 36 months, during which maintenance and repair events, and fuel use is recorded and used to compile life-cycle costs. At the conclusion of the 160,000 miles of fleet testing, the SAE J1634 tests are rerun and each HEV battery pack is tested. These AVTA testing activities are conducted by the Idaho National Laboratory, Electric Transportation Applications, and Exponent Failure Analysis Associates. This paper discusses the testing methods and results.
\end{abstract}

\section{INTRODUCTION}

The U.S. Department of Energy's (DOE) Advanced Vehicle Testing Activity (AVTA) is conducting hybrid electric vehicle (HEV) testing to support the AVTA's goal of providing benchmark data of emerging technologies for technology modeling, and research and development programs conducted by DOE and its industry partners. There is great interest in HEVs as an emerging technology as all automotive manufacturers are either currently offering HEVs or have made announcements of future HEV products. The HEV testing results are also provided to fleet managers and the general public to support their vehicle acquisition processes. Depending on operating scenario, HEVs can offer increased fuel economy or increased power, or both, by combining the use of traction battery packs and internal combustion engines.

The AVTA uses two primary HEV test methods. (1) Baseline performance testing is conducted on dynamometers and closed test tracks, allowing for a highly-controlled testing environment and vehicle-tovehicle comparisons of the testing results. (2) Fleet testing places HEVs in commercial fleets where 160,000 miles of fuel use, repairs, maintenance, and life-cycle costs (including insurance and depreciation costs) are collected for each vehicle within 36 months. The fleet testing provides a very real-world element to the testing process. The AVTA is part of DOE's FreedomCAR and Vehicle Technologies Program. These AVTA testing activities are conducted by the Idaho National Laboratory; by its testing partner, Electric Transportation Applications, Phoenix, Arizona; and by Exponent Failure Analysis Associates. Contractual management is provided by DOE's National Energy Technology Laboratory.

\section{BASELINE PERFORMANCE TESTING}

\section{BASELINE PERFORMANCE TESTING METHODS}

The baseline performance testing is conducted according to the AVTA's HEV Technical Specifications and $22 \mathrm{HEV}$ testing procedures ${ }^{1}$ which cover the testing process from required minimum vehicle specifications, through vehicle receipt, quality control, and testing methods which measure vehicle performance (acceleration times, top speed, handling, braking, gradeability, fuel economy, and traction battery capacity at the end of testing). Fuel economy is measured using Society of Automotive Engineers (SAE) J1634 May 93 Electric Vehicle Energy Consumption and Range Test Procedure. Other SAE testing standards used include: J1263 - Road Load Measurement and Dynamometer Simulation Using Coast Down Techniques and J1666 
May 93 - Hybrid Electric Vehicle Acceleration, Gradeability, and Deceleration Test Procedure.

The SAE J1634 drive cycle fuel economy tests, which include both the Urban Driving Schedule (1372 seconds) and Highway Fuel Economy Test Schedule (764 seconds), are conducted on a dynamometer in the following manner: two Urban Driving Schedules and two Highway Fuel Economy Test Schedules are conducted, followed by a 10 minute rest, and then two additional Urban Driving Schedules and two additional Highway Fuel Economy Test Schedules are conducted (UDS, UDS, HWFET, HWFET, 10 minute rest, UDS, UDS, HWFET, HWFET).

In an attempt to better understand the HEV technology before initiating formal baseline performance testing, AVTA and Southern California Edison conducted Pomona Loop testing on a Honda Insight and a Toyota Gen I Prius in 2001 and 2002. The testing results ${ }^{2,3}$ were somewhat mixed, but they did suggest probable significant fuel economy impacts when the air conditioning (AC) was used. For this reason, it was decided that the structured baseline performance SAE J1634 drive cycle testing would be conducted twice, once with the $A C$ off and again with the $A C$ on maximum.

The HEV testing procedures were developed to also incorporate the testing of HEVs in Rechargeable Energy Storage System (RESS) mode. However, none of the HEVs tested to date allow for extended all-electric, or RESS, operations.

\section{BASELINE PERFORMANCE TESTING RESULTS}

To date, baseline performance testing has been completed on seven HEV models: the Toyota Gen I and Gen II Prius; Honda Insight, Civic and Accord; Chevrolet Silverado (2 wheel drive); and Ford Escape (2 wheel drive). (The Highlander and RX400h will be tested early 2006). The results are discussed below.

\section{$\underline{\text { Vehicle Performance Testing Results }}$}

Because of historical electric vehicle testing methods, acceleration testing of the first three HEVs (Civic, Insight and Gen I Prius) was conducted from 0 to 50 miles per hour (mph); the remaining four HEVs were tested from 0 to $60 \mathrm{mph}$. All future HEVs will be tested from 0 to 60 $\mathrm{mph}$.

The Accord had the fastest acceleration time of 8.5 seconds (Figure 1). The maximum speed in the quarter mile ranged from $69 \mathrm{mph}$ for the Civic to $87 \mathrm{mph}$ for the Accord (Figure 2). The braking distances ranged from 134 feet for the Accord to 172 feet for the heavier Silverado during the controlled dry braking test (Figure 3). It should be noted that the Gen II Prius required 249 feet to brake during the controlled wet brake test. This was 47 feet longer than the next longest, the Silverado.

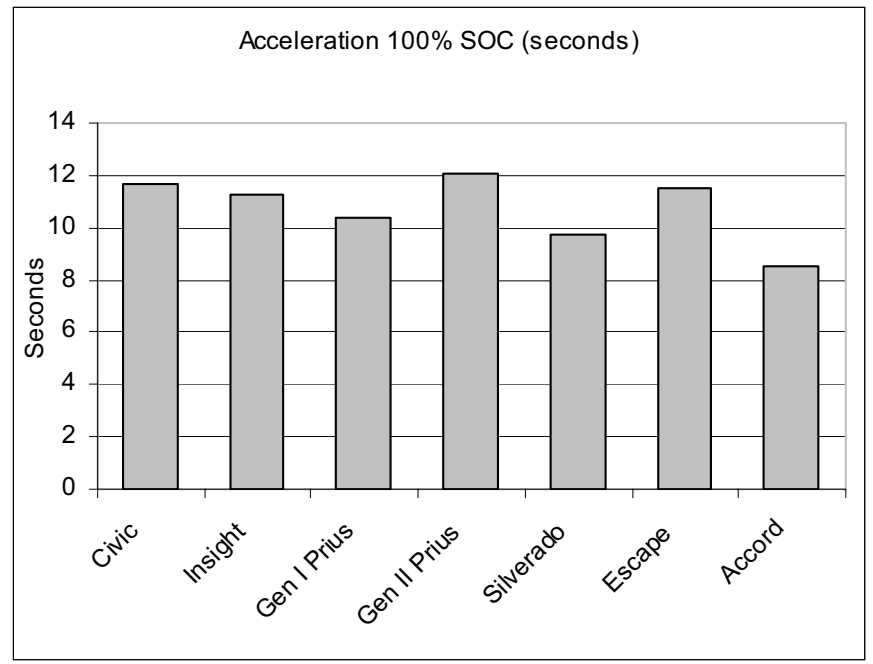

Figure 1. Acceleration testing results in seconds for the Civic, Insight and Gen I Prius (tested 0 to $50 \mathrm{mph}$ ), and for the remaining four HEVs (0 to $60 \mathrm{mph}$ ).

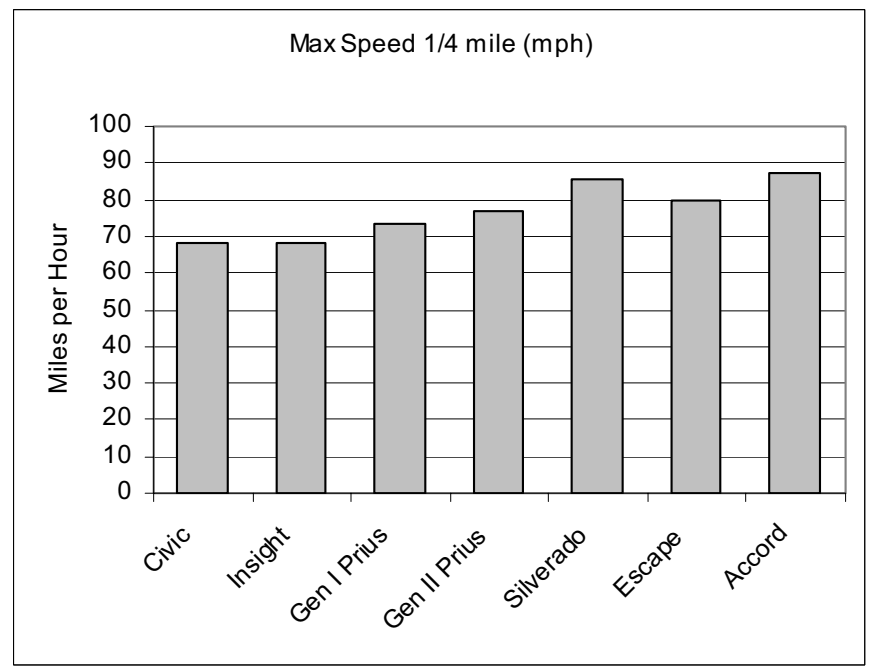

Figure 2. Testing results for HEV maximum speed in a quarter mile.

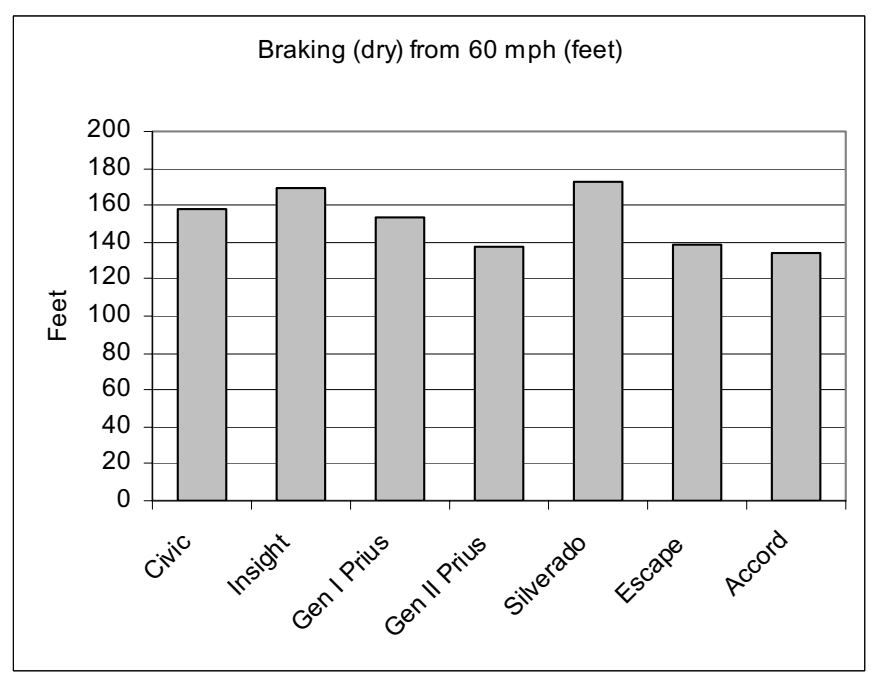

Figure 3. Testing results for HEV controlled dry braking from $60 \mathrm{mph}$. 


\section{Fuel Economy Testing Results}

One of each HEV model was SAE J1634 tested with the $A C$ off and again with the AC on maximum. The SAE J1634 testing results with the $A C$ off ranged from 18.8 miles per gallon ( $\mathrm{mpg}$ ) for the Silverado to $56.2 \mathrm{mpg}$ for the Insight (Figure 4). The average was $40.9 \mathrm{mpg}$ for the HEVs with the AC off during the SAE J1634 test.

When the identical SAE J1634 tests were conducted with the $A C$ on maximum, the results ranged from 16.0 $\mathrm{mpg}$ for the Silverado to $42.7 \mathrm{mpg}$ for the Insight (Figure 4). The average fuel economy with the $A C$ on maximum dropped to $31.9 \mathrm{mpg}$ from $40.9 \mathrm{mpg}$ with the $A C$ off.

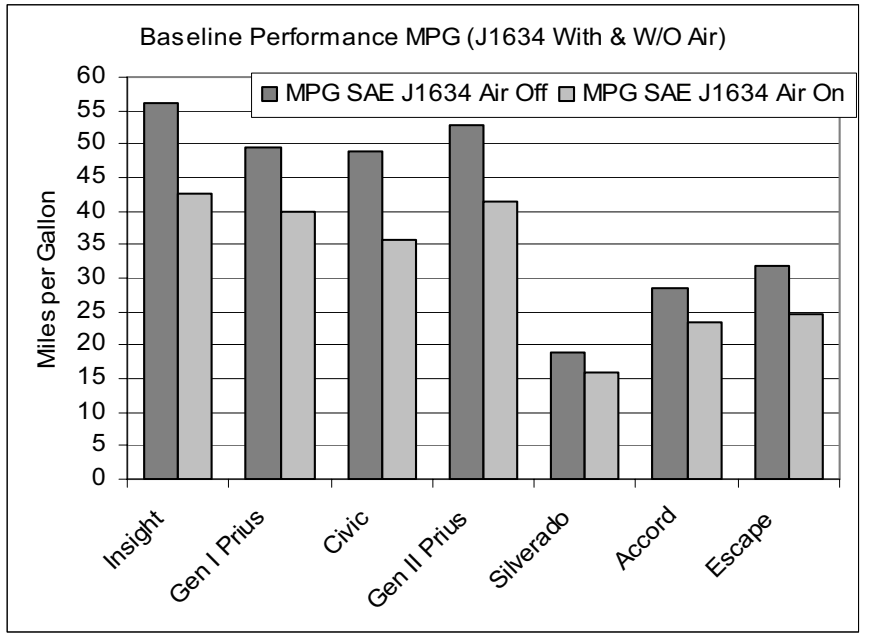

Figure 4. SAE J1634 fuel economy testing results with the $A C$ off and again with the $A C$ on.

Fuel economy decreases due to the use of $A C$ during the SAE J1634 tests were recorded for all the HEVs. The largest decrease recorded was $13.5 \mathrm{mpg}$ for the Insight. The smallest decrease recorded was $2.8 \mathrm{mpg}$ for the Silverado.

The Civic had the greatest percentage fuel economy decrease $(27.1 \%)$ when the AC was on during the SAE J1634 tests (Figure 5). The average decrease in fuel economy due to use of the AC during the SAE J1634 testing was $21.1 \%$.

\section{Battery Discharge During SAE J1634 Testing}

When SAE J1634 tests were conducted with and without the $A C$ on, traction battery discharge (Ah) was collected for each HEV. This data is presented in Figure 6, normalized to nominal battery capacity, such that $1 \mathrm{C}$ represents the discharge capacity equal to the nominal rated capacity of the HEV battery.

The test results ranged from $0.72 \mathrm{C}$ for the Silverado SAE J1634 test with the AC off, to $3.38 \mathrm{C}$ for the Gen II Prius SAE J1634 test with the AC on. The average normalized discharge for the AC-on SAE J1634 test was $1.95 \mathrm{C}$; for the AC-off test, it was $2.26 \mathrm{C}$.

The normalized discharged capacities are greater for each HEV during the AC-on SAE J1634 tests, except for the Gen I Prius and the Escape. The percentage increase ranged from $7.7 \%$ for the Accord to $52.1 \%$ for the Insight and $53.8 \%$ for the Gen II Prius. The normalized discharged capacity decreased $6.4 \%$ for the Gen I Prius and $27.8 \%$ for the Escape.

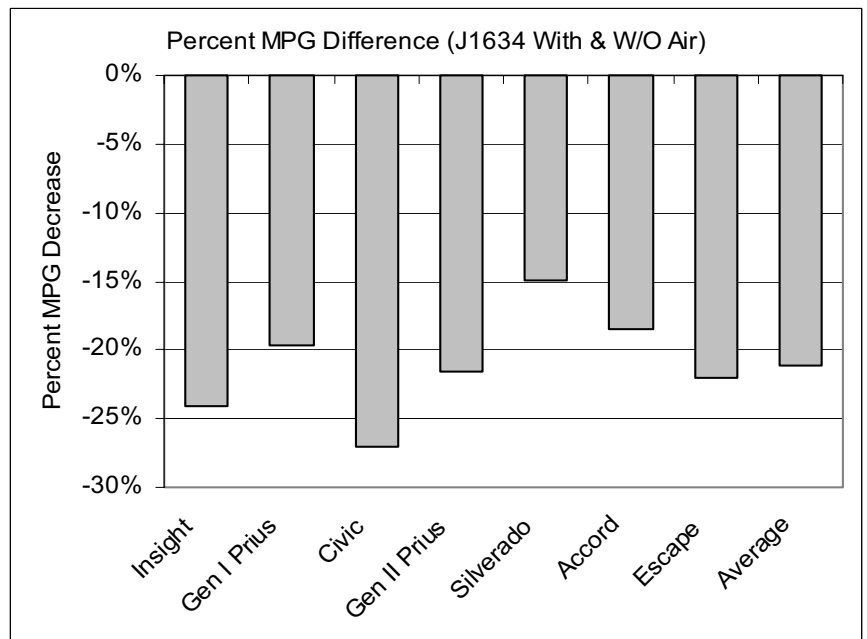

Figure 5. Percentage decrease in HEV fuel economy when the $A C$ is turned on maximum during the $S A E$ J1634 fuel economy testing.

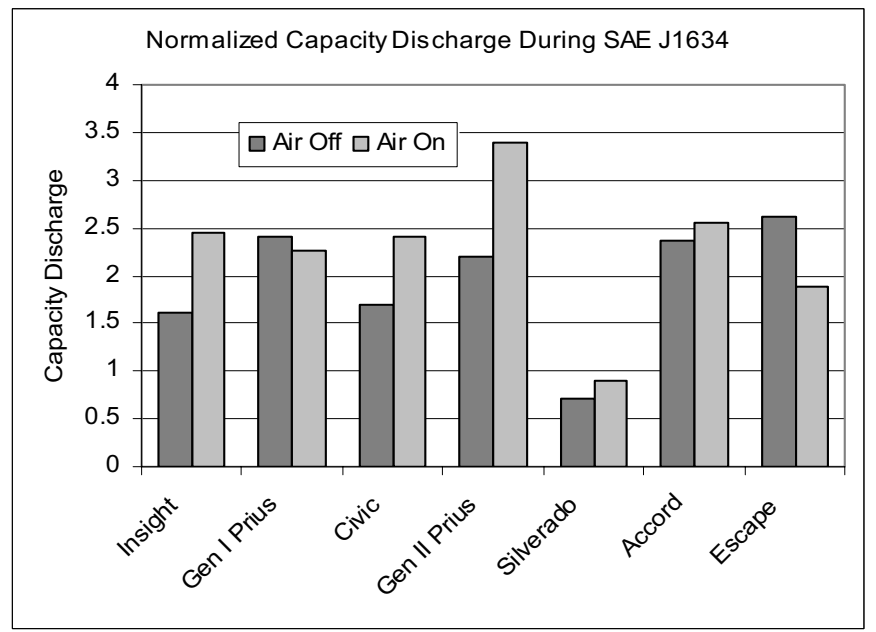

Figure 6. Capacity discharged from the HEV traction batteries during the SAE J1634 tests with the AC on and with the AC off.

\section{FLEET TESTING}

\section{FLEET TESTING BACKGROUND AND METHODS}

Originally, fleet testing consisted of two categories, (1) "regular" fleet testing, with no attempt to maximize mileage accumulation, and (2) accelerated reliability testing, with maximum effort to collect many miles in short periods of time. Prior to HEV testing, fleet testing usually meant accumulating 12,000 miles per test vehicle within 12 months. Only with dedicated drivers, and at times, significant exertion could additional mileage be accumulated on pure-electric vehicles. For instance, operating a pure-electric vehicle more than one discharge cycle per day required almost 24 hours per day of testing. 
The introduction and operating capabilities of HEVs allow the AVTA to place them in fleets that accumulate high mileages in abbreviated time frames as part of normal operations. For HEVs, this means accumulating up to 160,000 miles per test vehicle (Table 1) in 36 months on two of each HEV model tested. The benefit of accelerated mileage accumulation includes the accelerated accumulation of data, so vehicle engineers, modelers, and fleet managers get timely and meaningful life-cycle results.

Table 1. Number of HEV test vehicles and test status.

\begin{tabular}{lcc} 
Model & Number & Test Start/End Status \\
\hline Insight & 6 & Aug 01 - March 05 \\
Gen I Prius & 6 & Nov 01 - April 05 \\
Civic & 4 & May 02 - April 05 \\
Gen II Prius & 2 & Nov 03 - ongoing \\
Silverado & 2 & Sept 04 - ongoing \\
Accord & 2 & Jan 05 - ongoing \\
Escape & 2 & April 05 - ongoing \\
RX400h & 2 & May 05 - ongoing \\
Highlander & 2 & Start Oct 05 \\
\hline
\end{tabular}

While some of the early HEVs were only fleet tested for less than 25,000 miles, the testing results for these lower-mileage HEVs and the 160,000-miles HEVs are discussed here together. "Fleet testing" refers to both groups of vehicles. Fleet testing methods are based on the AVTA's Fleet Test and Evaluation Procedure. ${ }^{4}$ The HEVs are operated in several fleets in the greater Phoenix, Arizona area, including some use in Flagstaff, Arizona. The HEVs that accumulate 160,000 miles in 36 months are primarily operated by Bank One of Arizona.

To date, the $26 \mathrm{HEVs}$ that have entered fleet testing have accumulated over 1.4 million test miles (Figure 7). Note that both the Silverado and Escape HEVs in fleet testing include one 4 wheel drive (WD) and one 2WD per HEV model.

\section{FLEET TESTING FUEL ECONOMY RESULTS}

Fuel efficiencies for the HEVs in fleet testing range from $18.5 \mathrm{mpg}$ for the Silverado HEVs (18.7 mpg for the 4WD and 18.3 for the 2WD) to $45.1 \mathrm{mpg}$ for the Gen II Prius and $45.2 \mathrm{mpg}$ for the Insight (Figure 8). There is seasonal variation in fuel economies for the HEVs when viewed on a month-to-month basis; this is especially noticeable when viewing the fuel economy summary for the six Insights (Figure 9). The Insight fuel economy is clearly highest during the cool months and lowest during the warmest months, when AC use is highest. When the monthly fuel economy data is viewed for the HEVs that have accumulated the most fleet testing miles (Insight, Civic, Gen I Prius), a pattern of seasonal variation in fuel economy is apparent (Figure 10).

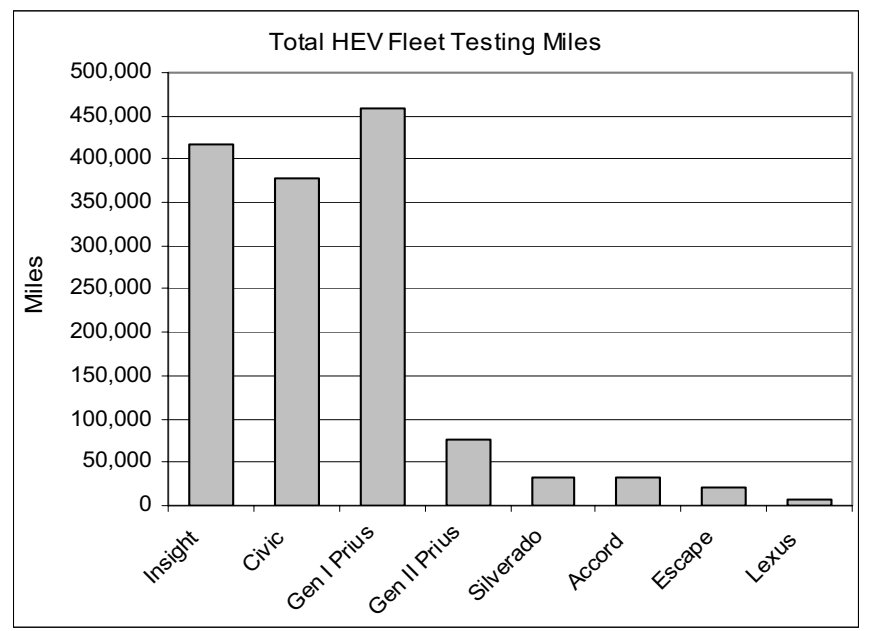

Figure 7. HEV fleet testing mileage accumulation by HEV model.

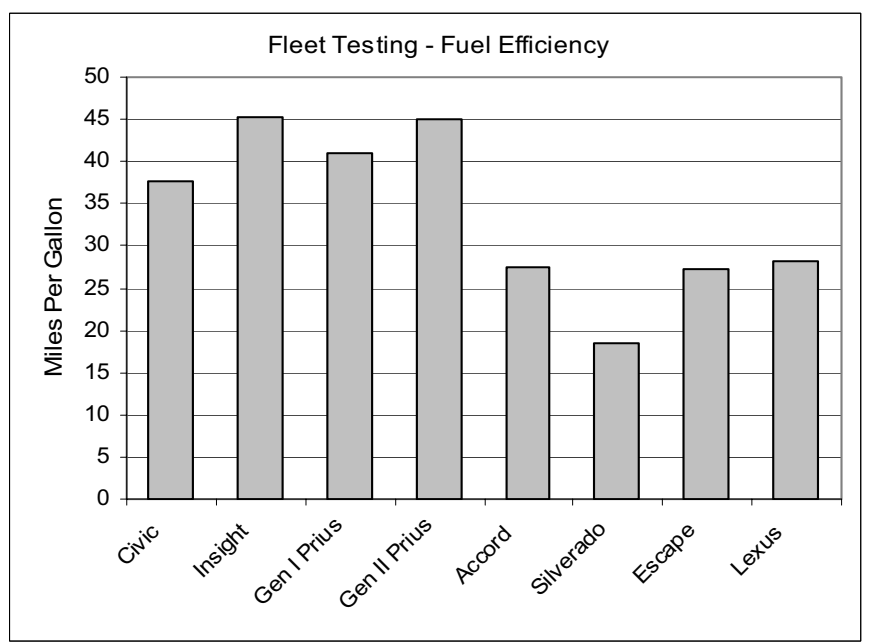

Figure 8. Fleet testing HEV fuel economy.

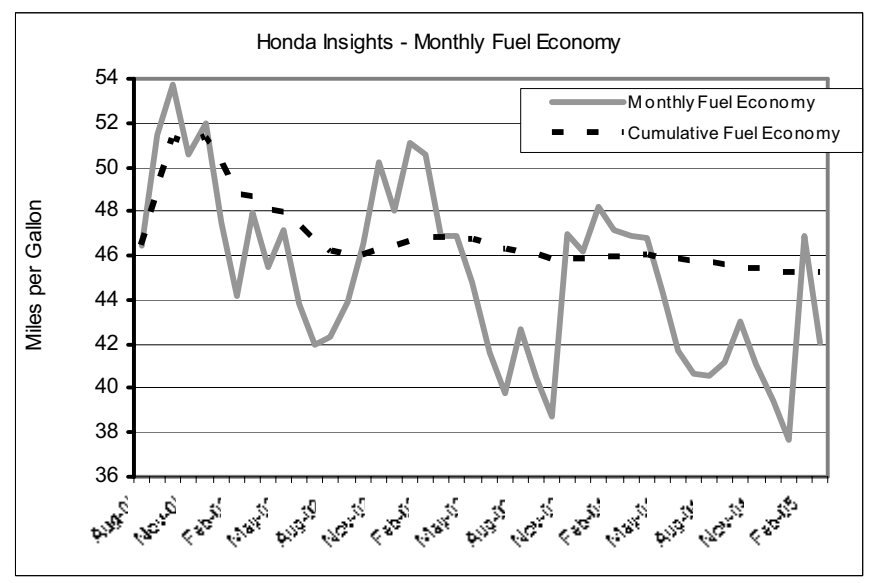

Figure 9. Monthly fuel economy for the six Insight HEVs in fleet testing.

The cool 3-months and hot 3-months seasonal variations for the 18 Insight, Civic, Gen I Prius and Gen II Prius HEVs can be seen in Figure 11. The Figure 11 results for the Gen II Prius represent about 30,000 fueldata miles. For the other three HEV models, the results represent about 200,000 fuel-data miles for each model. 
The miles for each HEV model in Figure 11 are about evenly split between the cool (December, January and February) and hot (June, July and August) months. The data in Figure 11 covers a total of 646,000 miles. Inasmuch as these fleet vehicles were driven in the greater Phoenix, Arizona area, the cool months are certainly not as cold as many other locations. However, the cool months are "cold" to Phoenix residents and the $A C$ is rarely used. It addition, the HEV data includes some use in Flagstaff, Arizona, which has colder average winter lows than Buffalo, New York.

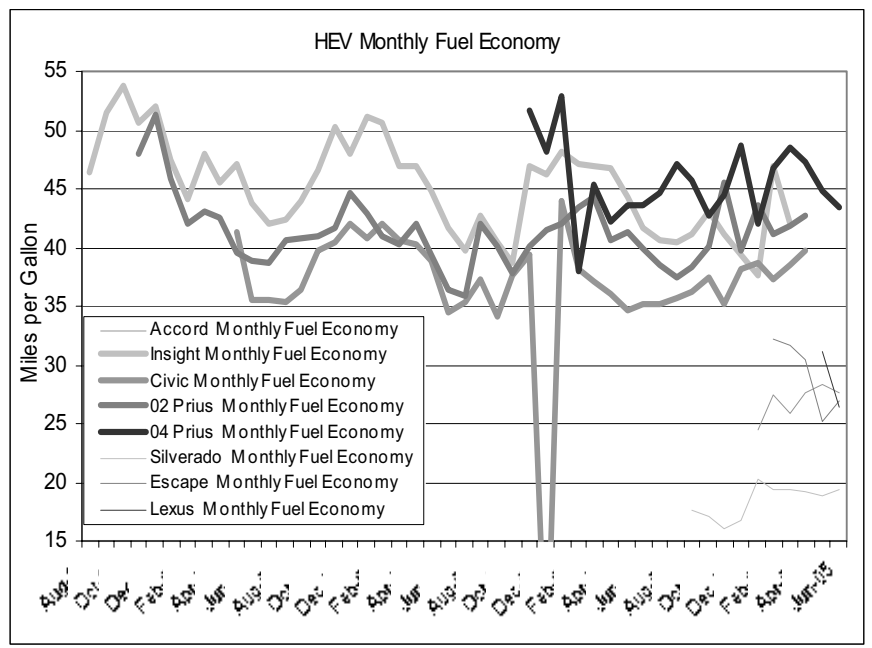

Figure 10. Monthly fuel economy for all HEVs. Note that the Honda Civic data for December 2004 was very low as both vehicles were in repair, and fueling events occurred but few miles were accumulated.

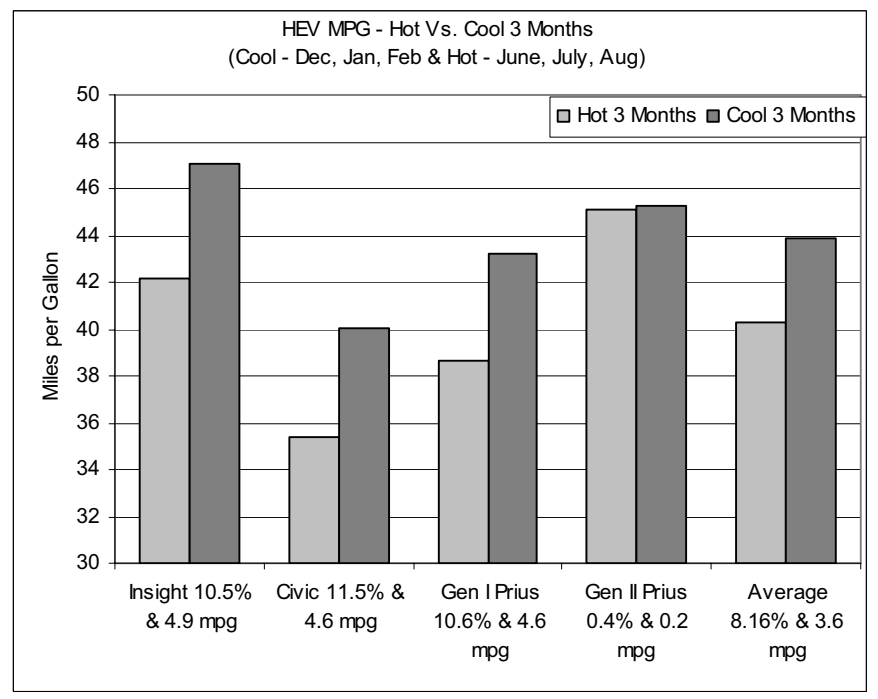

Figure 11. Cool and hot weather fuel economy results during HEV fleet testing.

The four HEV models experienced an average decrease in fuel economy during the hot months of $3.6 \mathrm{mpg}$ $(8.2 \%)$ compared to the fuel economy during the cool months. The largest percentage decrease in fuel economy occurred in the Civics, which had an $11.5 \%$ decrease.

\section{FLEET TESTING MAINTENANCE AND REPAIR REQUIREMENTS}

The maintenance and repair requirements for the HEVs are tracked and reported on a per-vehicle basis. The data collected and disseminated includes the date of repair or maintenance event, any action taken (oil changes to transmission and battery pack replacement), the miles on the vehicle when the event occurred, and the cost (or if under warranty) per repair or maintenance event.

In addition to the usual oil changes, tire replacements, and other normal repair and maintenance events, there were six Honda Insight and Civic CVT transmission failures, one Insight traction battery pack failure, several engine control module failures, and two Gen I Prius rack-and-pinion failures; these failures occurred during 1.2 million test miles. Maintenance and repair data sheets, and fleet testing fact sheets can be found for each HEV on the AVTA's Hybrid Electric Vehicle webpages. ${ }^{5}$ The maintenance and repair data has been summarized on a cost-per-mile basis and used as input to determine the life-cycle costs discussed in the next section.

\section{FLEET TESTING LIFE-CYCLE COSTS}

All of the costs incurred to operate the HEVs, with the exception of collision repair costs, are used to calculate the operating costs per mile for 20 Insight, Civic, Gen I and Gen II Prius, and Silverado HEVs (Figures 12 and 13). To date, 14 of the 16 Insights, Civics, and Gen I Prius HEVs have been sold, and the actual sale prices are used for the residual value to calculate the ownership cost. Private-party Kelly Blue Book values for two Insights that remain in non-testing use as well as the two Gen II Prius and two Silverado HEVs are used to calculate residual values.

The life-cycle costs for the high mileage HEVs (one Insight at 146,000 miles and the other five HEVs at 160,000 to 165,000 miles) average 21.5 cents per mile (Figure 12). The highest mileage HEV (Gen I Prius) had the lowest life-cycle cost of 17.7 cents per mile. The HEV (Insight) with the lowest mileage (146,000 miles) in Figure 12 had the highest cost of 26.9 cents per mile. This group of HEVs had relatively low registration and insurance costs per mile as these costs only occurred for the three years the vehicles were operated. Most HEVs, and all internal combustion engine vehicles in general, would normally accumulate 10 or more years of registration and insurance costs while being operated for 160,000 miles.

The lower-mileage HEVs in Figure 13 had an average life-cycle cost of 54.3 cents per mile. The costs ranged from 131.3 cents $(\$ 1.31)$ per mile for the Insight with only 9,000 miles accumulated in 15 months, to 23.7 cents per mile for the Gen li Prius which has accumulated 60,000 miles in 23 months to date. 


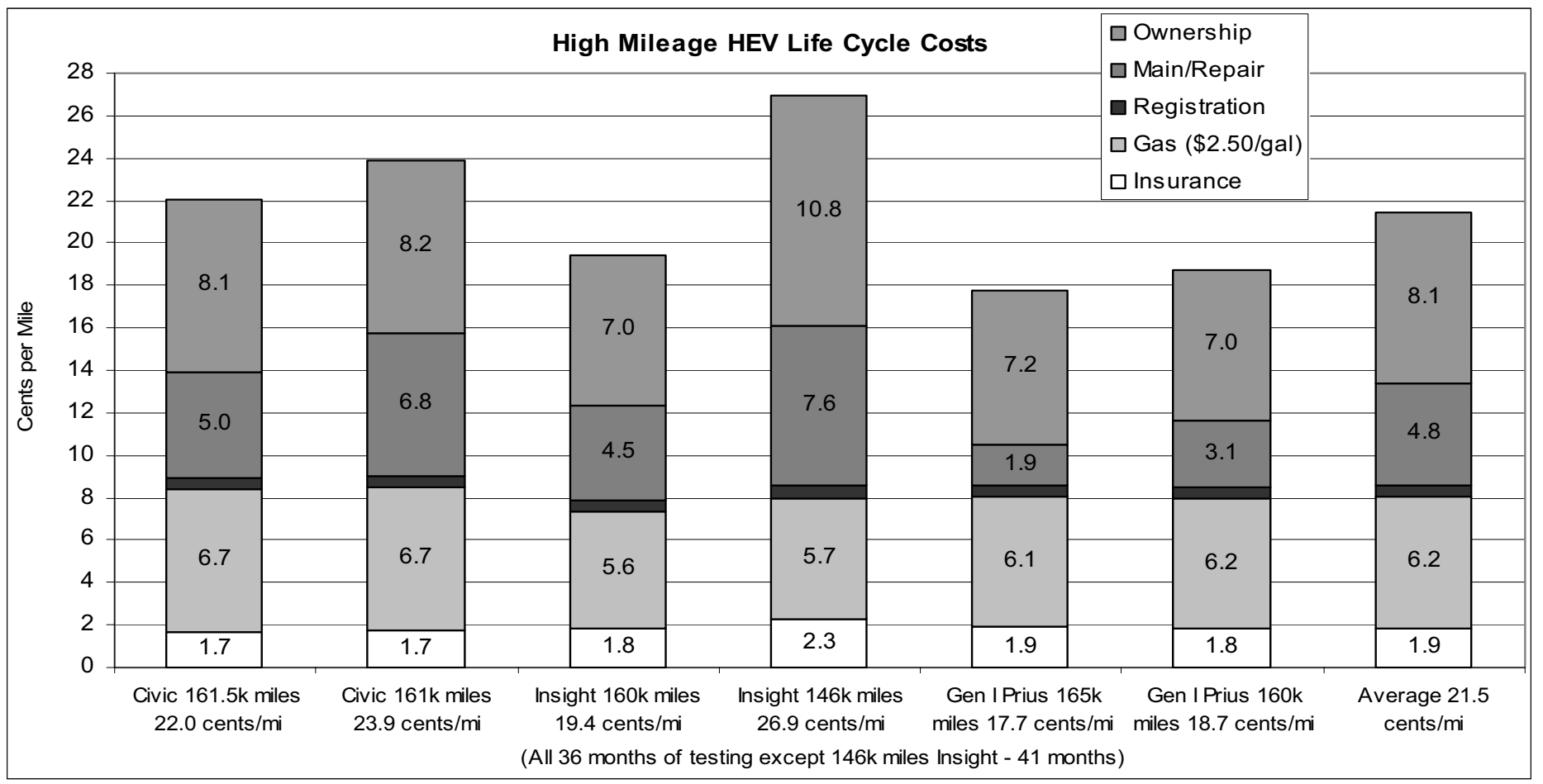

Figure 12. Life-cycle vehicle costs (cents) per mile for high-mileage HEVs (146,000 to 165,000 miles). All maintenance and repair costs are included, except any costs arising from vehicle collisions. The costs also include ownership (purchase minus sale prices), registration, gasoline at $\$ 2.50$ per gallon, and insurance.

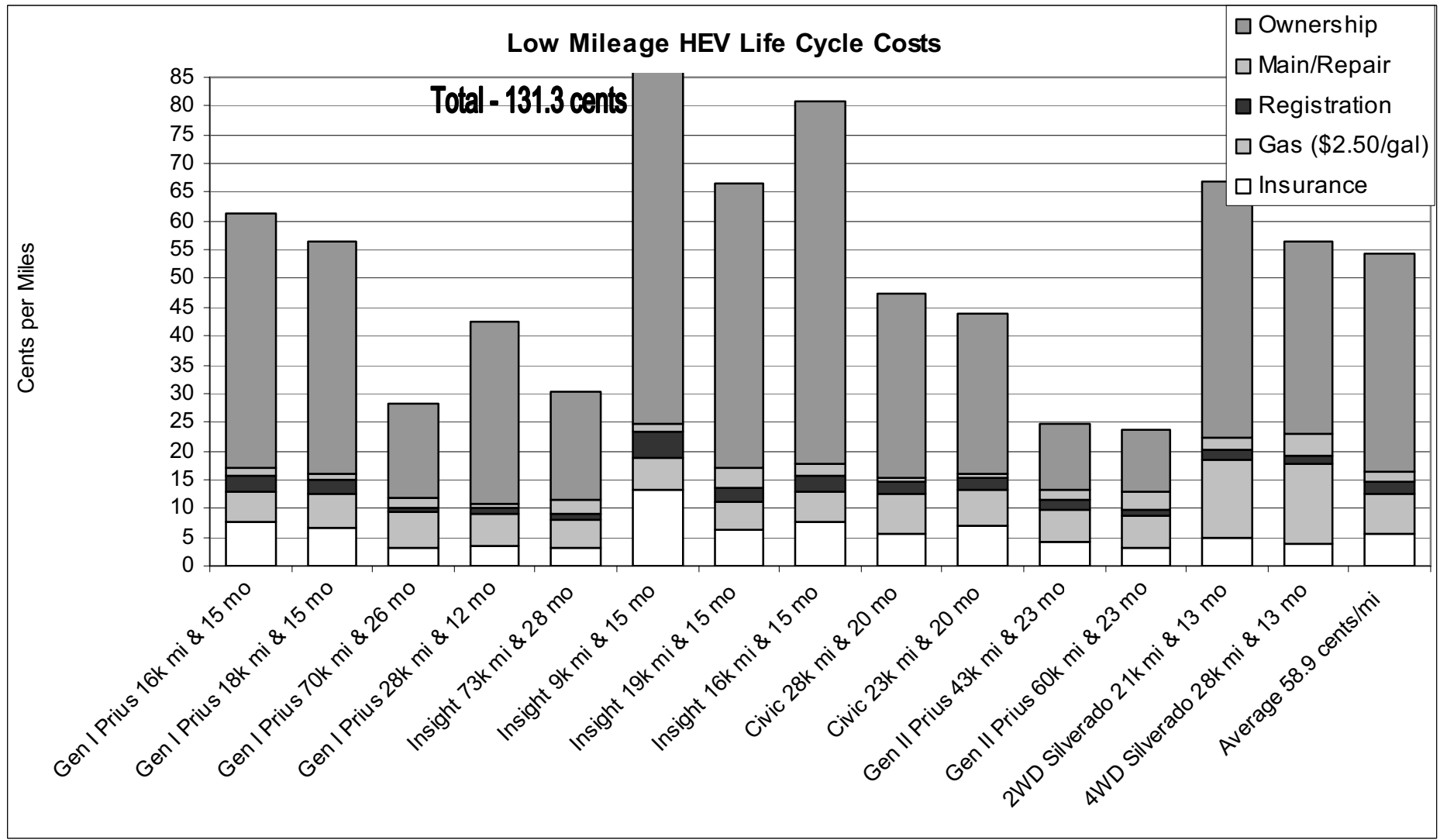

Figure 13. Life-cycle vehicle costs (cents) per mile for lower-mileage HEVs. All maintenance and repair costs are included, except any costs arising from vehicle collisions. The costs also include ownership (purchase minus sale prices), registration, gasoline at $\$ 2.50$ per gallon, and insurance. The 9,000 miles Insight's costs total 131.3 cents per mile.

The largest contributor of the higher per-mile-costs for the lower-mileage HEVs is the ownership cost (purchase minus sale prices). The lower-mileage HEVs in Figure
13 have an average ownership cost of 37.9 cents per mile, while the high-mileage HEVs in Figure 12 have an average ownership cost of 8.1 cents per mile. The 29.8 
cents per mile difference in ownership costs is almost equal $(91 \%)$ to the average 32.8 cents per mile total cost difference between the high-mileage and low-mileage HEVs.

As anticipated, the repair and maintenance costs per mile accelerate as the HEVs age. The lower-mileage HEVs have an average cost of 1.9 cents per mile for repairs and maintenance, while the higher-mileage HEVs have an average repairs and maintenance cost 2.5 times higher (4.8 cents per mile).

As a reference point, the United States Federal Government reimburses drivers of private vehicles at the rate of 48.5 cents per mile (as of September 1, 2005). Unfortunately, limited funding does not allow for the testing and data collection on non-HEV internal combustion engine vehicles in similar fleets.

\section{END-OF-LIFE (160,000 MILES) TESTING}

\section{INTRODUCTION}

To characterize the effects of high mileage on fuel economy and traction battery pack capacity, each 160,000-miles HEV was subjected to SAE J1634 retesting with and without the $A C$ on. In addition, traction battery pack capacity and power tests were performed in accordance with the FreedomCAR Battery Test Manual For Power-Assist Hybrid Electric Vehicles ${ }^{6}$ procedures. The battery tests consisted of a static capacity test with a low discharge rate and the Hybrid Pulse Power Characterization (HPPC) test with a short duration, high discharge rate, to simulate peak loading observed during the SAE J1634 driving cycle. Other than manufacturerrecommended scheduled maintenance and preparation requirements for each test procedure, none of the vehicles or their traction battery packs were specially prepped for any of the tests. The end-of-life battery testing methods and results are presented below. Note that one of the Insights (Insight 2) was end-of-life tested at 146,000 miles. This HEV's transmission and other components required repairs that were deemed too expensive to undertake at 146,000 miles.

\section{END-OF-LIFE BATTERY TESTING}

\section{End-of-life Battery Test Methods}

The traction battery pack capacity of each HEV was characterized in accordance with test procedure ETAHTP14, August $1,2005,{ }^{7}$ for static capacity and the HPPC test. To ensure consistency, all vehicle testing was performed in a temperature-controlled environment and with identical test protocol.

For the static capacity test, the battery pack for each end-of-life HEV was conditioned to a full state-of-charge (SOC) in accordance with the battery manufacturer's recommended charging procedures, terminating the charge after the pack voltage had reached its peak voltage and then dropped 10 milli-volts per cell. After the full charge and an eight-hour rest period to allow for cell stabilization, the battery pack was discharged at its C1 discharge rate (the current equal to the manufacturer's one-hour nominal capacity rating). The battery pack was discharged until the average cell voltage across the battery pack was 1.00 volts per cell. The total ampere-hours (Ah) delivered by the battery pack were recorded, thus completing one charge/discharge cycle. This procedure of charging and discharging (cycling) was repeated until the results of three consecutive cycles yielded an Ah discharge rate that did not vary more than $3 \%$ between three consecutive tests.

The HPPC testing was performed to determine the SOC at which the battery pack could no longer comply with the power demanded by the HEV motor controller during an SAE J1634 drive cycle (the same cycle upon which fuel economy data is obtained). To determine the parameters required to conduct the HPPC test, i.e. the magnitude of the charge and discharge pulse, the peak power demand from the SAE J1634 drive cycle baseline testing for each vehicle type was examined.

From this data, the top $0.5 \%$ battery pack charge current data was averaged to provide a single charge current value. This charge current value was used to represent the magnitude of the charge pulse for HPPC testing. Similarly, the top $0.5 \%$ discharge current data was averaged to provide a single value used to establish the magnitude of the HPPC test discharge pulse.

With the magnitude of the charge and discharge pulse established, the battery pack was subjected to a single pulse discharge and single pulse charge at each percent SOC level, starting at $90 \%$ and decrementing at $10 \%$ SOC intervals until the battery pack voltage reached an average of 0.8 volts per cell.

Between each test cycle, which consisted of one charge/discharge pulse at each percent SOC level, the battery pack was discharged at its $\mathrm{C} 1$ rate to reach the next $10 \%$ SOC interval. Upon reaching the termination criterion, the percent $\mathrm{SOC}$ and its equivalent Ah rating were recorded.

Although summarized above, a more detailed account of the HPPC test protocol included fully charging each battery pack by performing one $\mathrm{C} 1$ cycle as described in the static capacity test, followed by a one-hour rest period to allow for cell stabilization. At the end of this rest period, the battery was discharged at the $\mathrm{C} 1$ rate until it reached $90 \%$ SOC based on the nominal C1 Ah rating of the battery, (i.e. nominal $\mathrm{C} 1$ battery rating in $\mathrm{Ah}$ times 0.9). Immediately following a one-hour rest period, the battery pack was subjected to a ten-second discharge pulse of the discharge magnitude determined in the method above. A forty-second rest period was observed followed by a ten-second current charge pulse of the charge magnitude determined in the method above. After the discharge/charge pulse, the battery pack was discharged at a $\mathrm{C} 1$ rate until it reached $80 \%$ 
SOC, immediately followed by a one-hour rest period. This pulse sequence was continued, removing $10 \%$ of SOC each time, until the battery pack voltage averaged 0.8 volts per cell during the $\mathrm{C} 1$ discharge portion, at which point the test was terminated (the battery pack voltage was protection-limited to an average 0.8 volts per cell). If the voltage reached an average of 0.8 volts per cell at any point during a discharge pulse, the current was decreased until the pulse duration was complete. In this way, the battery pack was protected from over-discharge. An upper limit of 1.8 volts per cell was also placed on the battery during the charge pulse portion of the test to protect the battery from overcharge.

\section{End-of-life Battery Test Results}

Since the initial traction battery pack capacity of each HEV was not determined when the vehicle was new, the characterization results obtained from the end-of-life testing were compared to the nominal (manufacturer) rated battery capacity.

For static battery pack capacity testing, each end-of-life HEV demonstrated a diminished battery pack capacity (Figure 14). The two Civics demonstrated an average $31.7 \%$ reduction in battery pack capacity, the two Insights an average $15.8 \%$ reduction in battery pack capacity, and the two Gen I Prius an average $61.0 \%$ reduction in battery pack capacity.

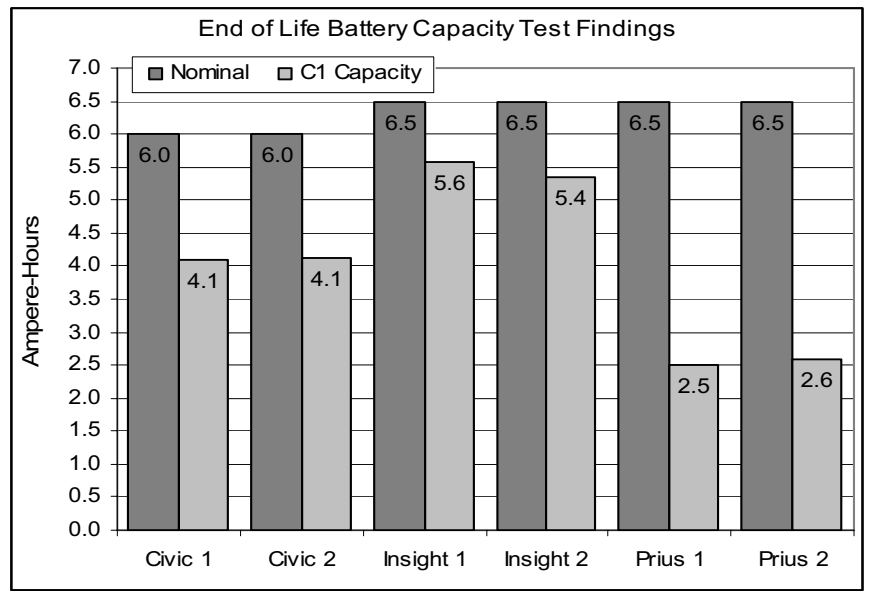

Figure 14. End-of-Life HEV battery capacity test findings.

The HPPC findings (Table 2) suggest a qualitative measure of the capability (range of working capacity) of each end-of-life HEV battery pack to meet a short-term, high-load demand that is representative of a typical drive cycle. Although in the future, an updated test procedure will require the HPPC test procedure to be performed on new HEV battery packs, HPPC testing was not performed on the subject HEVs $(160,000$ miles end-oflife fleet test) when the vehicles were new. The corresponding percent SOC at termination and the SOC step at which a discharge pulse was limited, as determined by HPPC testing, is displayed in Table 2 . The lower the percentage SOC displayed in Table 2, the greater its capability is to meet the power demand of the motor controller at the discharge loads observed during the HPPC test. All batteries tested were capable of absorbing the charge pulses without reaching the voltage limit placed on them, including the charge pulse at $90 \%$ SOC. Therefore it is reasonable to conclude that the battery's ability to absorb energy had not degraded as a result of fleet testing. Also displayed in Table 2 are the pulse charge and pulse discharge currents used in the HPPC testing, as well as their corresponding C Rate (the current value divided by the battery's nominal $\mathrm{C} 1$ rating).

Table 2. End-of-Life HPPC test findings of percent SOC at test termination.

\begin{tabular}{lcccc}
\hline $\begin{array}{l}\text { End-of- } \\
\text { Life } \\
\text { HEV }\end{array}$ & $\begin{array}{c}\text { Percent SOC } \\
\text { at Discharge } \\
\begin{array}{c}\text { Pulse } \\
\text { Voltage Limit }\end{array}\end{array}$ & $\begin{array}{c}\text { Percent } \\
\text { SOC at } \\
\text { test end }\end{array}$ & $\begin{array}{c}\text { Charge } \\
\text { Pulse Amps / } \\
\text { C Rate }\end{array}$ & $\begin{array}{c}\text { Discharge } \\
\text { Pulse Amps / } \\
\text { C Rate }\end{array}$ \\
\hline Civic 1 & $30 \%$ & $23.0 \%$ & $71.6 / 11.9$ & $-68.4 /-11.4$ \\
Civic 2 & $50 \%$ & $41.6 \%$ & $71.6 / 11.9$ & $-68.4 /-11.4$ \\
Insight 1 & $10 \%$ & $5.9 \%$ & $78.7 / 12.1$ & $-65.7 /-10.1$ \\
Insight 2 & $10 \%$ & $8.2 \%$ & $78.7 / 12.1$ & $-65.7 /-10.1$ \\
Prius 1 & $60 \%$ & $52.4 \%$ & $53.4 / 8.2$ & $-78.9 /-12.1$ \\
Prius 2 & $*$ & $51.2 \%$ & $53.4 / 8.2$ & $-78.9 /-12.1$ \\
\hline${ }^{*}$ HPPC discharge pulse not limited due to minimum battery voltage
\end{tabular}

* HPPC discharge pulse not limited due to minimum battery voltage

\section{END-OF-LIFE SAE J1634 FUEL ECONOMY TESTING}

\section{End-of-life SAE J1634 Testing Description}

Prior to traction battery capacity testing, each HEV that participated in the 160,000 mile fleet test was subjected to SAE J1634 testing in accordance with procedure ETA-HTP03, dated May 1, 2004. This procedure consists of testing each HEV on a double-roller, singledrive-axle chassis dynamometer operating in an environmentally controlled chamber in accordance with the operational and temperature requirements of SAE J1634. A total of four Urban Driving Schedule (UDS) test cycles and four Highway Fuel Efficiency Test (HWFET) driving cycles were performed on each vehicle with the $A C$ off and then with the AC on maximum. The test vehicle parameters recorded include roller speed, accumulated distance, indicated traction battery pack voltage, indicated traction battery pack current, and ambient temperature.

Fuel economy testing was conducted in two phases. Phase I tested all six of the fleet test HEVs on the dynamometer using road load coefficients obtained from baseline performance testing of the HEVs prior to fleet testing (i.e. when the vehicles were new or nearly new). These road load coefficients were those used to obtain fuel economy test results for the vehicles during baseline performance testing. The objective of Phase I fuel economy testing, was to determine if the degradation in battery capacity over 160,000 miles of fleet testing resulted in a concomitant degradation in fuel economy. The road load coefficients obtained from baseline performance testing were used to ensure that the vehicle was tested after 160,000 miles of fleet testing 
under the same loading conditions for which it was tested when it was new (baseline performance testing), thereby allowing a more direct comparison of fuel economy obtained when the vehicle was new (baseline performance testing) with fuel economy obtained after 160,000 miles of fleet testing. It should be noted that road load coefficients obtained for Phase I fuel economy testing were obtained from one vehicle of each HEV model. Road load coefficients obtained during baseline performance testing were obtained from vehicles identical to the fleet test HEVs, but not the actual fleet test vehicle.

In Phase II fuel economy testing, one of the two 160,000 mile Toyota Prius, one of the two 160,000 mile Honda Insights and one of the two 160,000 mile Honda Civics tested in Phase I were coast down tested in accordance with procedure ETA HTP01, dated November 1, 2004. This procedure implements the requirements of SAE J1263 for obtaining road load coefficients from test-track-obtained coast down data. These road load coefficients were then used to conduct SAE J1634 fuel economy tests. The results of this testing more accurately reflect the actual fuel economy of the HEVs tested after 160,000 miles of fleet testing and include effects of not only battery degradation (as in Phase I testing), but changes in drive train efficiency, rolling resistance and aerodynamic drag.

To summarize, all six end-of-life $(160,000$ miles) HEVs were SAE J1634 tested during Phase I testing, and only one of each end-of-life HEV model was SAE J1634tested during Phase II testing. Phase I and Phase II testing both included conducting the SAE J1634 tests with the $A C$ on and with the $A C$ off.

\section{End-of-life SAE J1634 Testing Results}

The fuel economy test results from Phase I and Phase II were compared with the fuel economy test results obtained on each of the HEV models during baseline performance testing (new or nearly new vehicle). Although the fuel economy data presented as new for each vehicle type was not collected specifically on the vehicles tested in Phase I and Phase II, it is reasonable to assert that a new vehicle, when tested under standardized conditions (which is the case for the data presented as new in this section), should yield a fuel economy result representative of the vehicles tested in Phase I and Phase II when they were similarly new. Therefore, for sake of comparison, the data presented as new will be used as the baseline for comparison to characterize the fuel economy findings for each of the end-of-life HEVs.

The findings for SAE J1634 fuel economy testing are presented in Figures 15 and 16 . In these Figures, the test results from Phase I and Phase II are compared to the baseline test (new) fuel economy values to determine if any changes in fuel economy have occurred during the course of the 160,000 miles of fleet testing.
Phase I testing was performed with road load coefficients from baseline performance testing. The Phase I AC-off (Figure 15) testing demonstrates an average $2.4 \%$ increase (improvement) in fuel economy for the Civics, an average $0.7 \%$ decrease in fuel economy for the Insights, and an average $4.2 \%$ increase in fuel economy for the Prius. In Figure 16, the Phase I, AC-on test results show an average fuel economy increase of $2.5 \%$ for the Civics, $4.2 \%$ for the Insights and $1.4 \%$ for the Gen I Prius. These changes are all considered within the accuracies (can be up to a $5 \%$ change when different vehicle operators are used) of the dynamometer testing. Therefore, the fuel economy results for the HEVs after 160,000 miles of fleet testing (when evaluated using road loads representative of a new vehicle) are equivalent to that of a new vehicle.

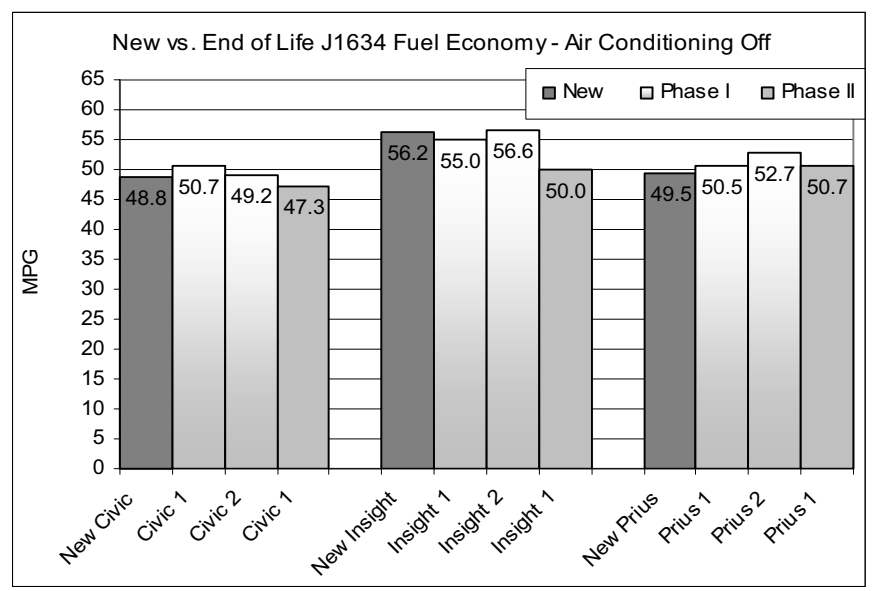

Figure 15. New versus end-of-life HEV SAE J1634 fuel economy results with the $A C$ off.

For Phase II AC-off testing (Figure 15), the data shows a $3.1 \%$ decrease in fuel economy for the Civic, an $11.0 \%$ decrease for the Insight, and a $2.4 \%$ increase for the Prius. For Phase II AC-on testing (Figure 16), the data demonstrates fuel economy decreases of $4.2 \%$ for the Civic, $11.5 \%$ for the Insight, and $5.0 \%$ for the Prius. These decreases in fuel economy result from the increased road load generated by the Phase II road load coefficients, with its accompanying increase in demand on the propulsion system.

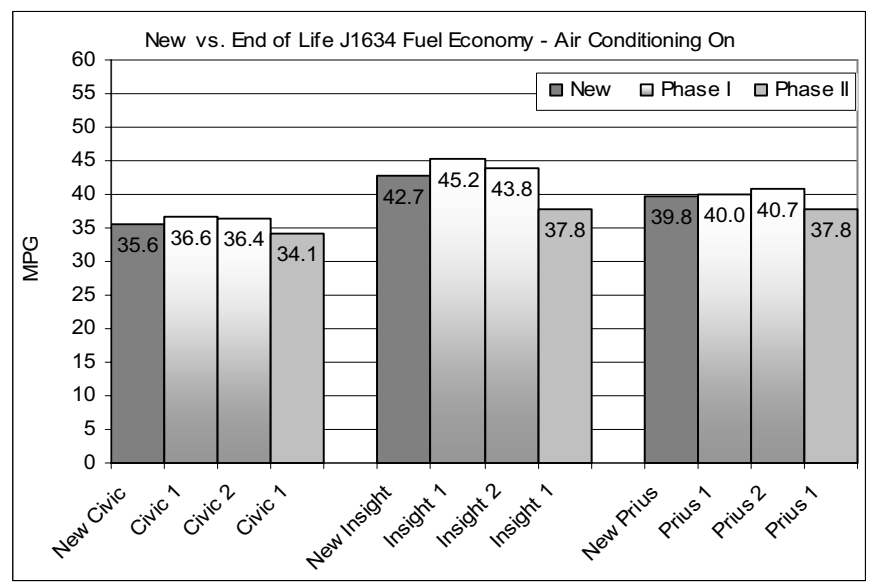

Figure 16. New versus end-of-life HEV SAE J1634 fuel economy results with the $A C$ on. 
This increased demand on the propulsion system can be demonstrated when battery capacity expended per mile during Phase II SAE J1634 fuel economy testing is compared to similar data from the baseline performance (new vehicle) fuel economy test results in Figure 17. (Note: baseline performance test data for the Prius was not collected using a methodology consistent with that of the Insight and Civic and is, therefore, not presented for comparison to the end-of-fife Gen I Prius data). The data presented in Figure 17 was normalized for a crossvehicle comparison by taking the overall energy output (in Ah) for the battery pack over the SAE J1634 test and dividing it by the nominal (manufacturer) battery capacity (in Ah). Dividing this battery value (energy output/nominal battery capacity) by the distance traveled during testing yielded a percent battery pack capacity usage value per mile (Figure 17).

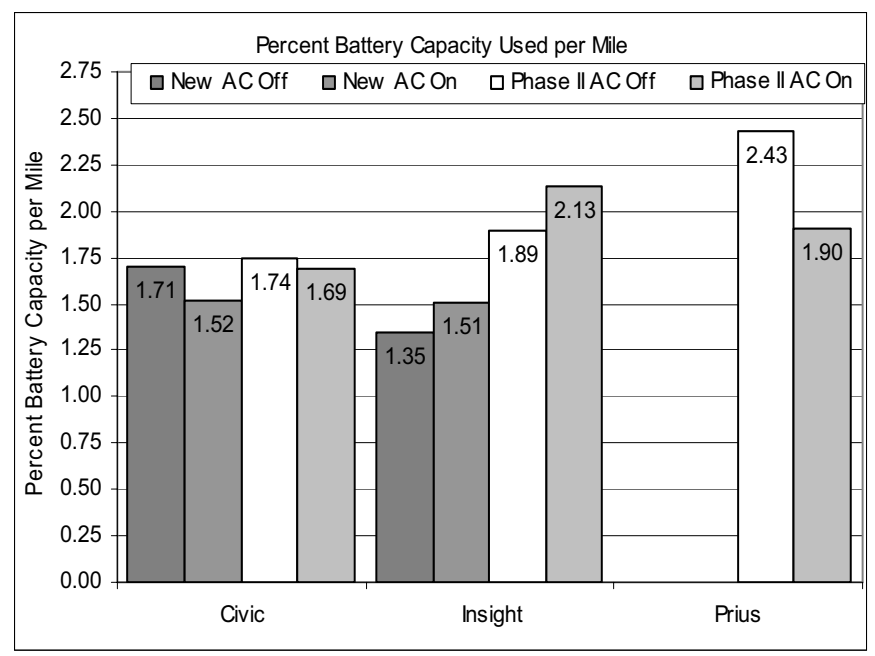

Figure 17. New and end-of-life HEV percentage battery capacity use per mile.

During Phase II fuel economy testing, the vehicle's onboard fuel economy display was recorded and compared to the actual Phase II fuel economy findings (Table 3). For every case and vehicle tested, it was observed that the on-board vehicle computer displayed a fuel economy higher than the actual measured SAE J1634 fuel economy.

Table 3. Phase II SAE J1634 fuel economy compared to the onboard-vehicle-computer-reported fuel economy.

\begin{tabular}{lc}
\hline $\begin{array}{l}\text { End-of-life Phase II } \\
\text { Test HEV }\end{array}$ & $\begin{array}{c}\text { Onboard computer fuel economy percentage } \\
\text { above the SAE J 1634 fuel economy results }\end{array}$ \\
\hline Civic 1 AC off & $+21.7 \%$ \\
Civic 1 AC on & $+21.0 \%$ \\
Insight 1 AC off & $+11.0 \%$ \\
Insight 1 AC on & $+11.7 \%$ \\
Gen I Prius 1 AC off & $+15.7 \%$ \\
Gen I Prius 1 AC on & $+14.7 \%$ \\
\hline
\end{tabular}

\section{FURTHER DISCUSSION OF END-OF-LIFE TESTING RESULTS}

Based on comparing the limited end-of-life test results to the baseline performance (new vehicle) test results, the data suggests that powertrain reliance on obtaining propulsion energy from the battery pack increases in the Insight and Civic (Figure 17) as they age. Coupled with the fact that all of the end-of-life HEVs tested had a decrease in battery pack capacity (Figure 14), these factors are not the only variables influencing a change in fuel economy, as the Gen I Prius demonstrates by having a $61.6 \%$ reduction (highest change of the three Phase II vehicles) in battery pack capacity and an average decrease in fuel economy (Phase II, AC-off and AC-on combined) of only $1.3 \%$ (lowest change of the three Phase II vehicles).

The Insight data also suggests that battery capacity reduction and a greater reliance on the battery pack to supply propulsion energy does not play a dominant role in affecting fuel economy as shown by the end-of-life Insight's $14.0 \%$ reduction (least change of the three, Phase II vehicles) in battery pack capacity and $11.3 \%$ decrease (highest change of the three, Phase II vehicles) in fuel economy (Phase II, AC-off and AC-on combined).

Other factors that may have affected fuel economy in the baseline and end-of-life comparisons are drive train efficiency changes, sample size (greater funding would allow a higher number of vehicles participating in the end-of-life testing) and vehicle operator variability (future testing will make it a goal to limit the use of different vehicle operators).

As a byproduct of fuel economy testing, it was observed that obtaining specific road load (coast down) coefficients for each vehicle prior to Phase II testing resulted in a change in fuel economy for the vehicles that participated in Phase I and Phase II. Although not conclusive based on the limited sample size, the end-oflife vehicles, due to their somewhat varied driving history, may well press the consideration to re-establish coast down coefficients. The concern does not normally arise when testing a new production vehicle, as it is a common industry practice to use coast down coefficients established on a new vehicle of the same type (make, model, and year) when performing fuel economy testing. However, the nature of end-of-life testing, and the corresponding vehicle condition that may result from this testing, may very well require the re-establishment of coast down coefficients to ensure the usefulness of this laboratory test procedure in predicting life-cycle fuel costs. As shown in Table 4, a suggested trend or correlation appears between changes in coast down times (55-45 mph) and changes in fuel economy.

Table 4. Phase I and Phase II fuel economy change due to retested coast down times (Prius is Gen I Prius).

\begin{tabular}{|c|c|c|c|c|c|}
\hline $\begin{array}{l}\text { End-of- } \\
\text { life HEV }\end{array}$ & $\begin{array}{r}55 \text { to } \\
45 \mathrm{mph} \\
\% \\
\text { change } \\
\end{array}$ & $\begin{array}{r}20 \text { to } \\
10 \mathrm{mpg} \\
\% \\
\text { change } \\
\end{array}$ & $\begin{array}{r}\% \text { Change in } \\
\text { fuel economy } \\
\text { Phase I \& II } \\
\text { AC off }\end{array}$ & $\begin{array}{r}\% \text { Change in } \\
\text { fuel economy } \\
\text { Phase I \& II } \\
\text { AC on }\end{array}$ & $\begin{array}{r}\text { Change } \\
\text { in fuel } \\
\text { economy }\end{array}$ \\
\hline Civic & $-7.5 \%$ & $-14.3 \%$ & $-5.3 \%$ & $-6.6 \%$ & $-6.0 \%$ \\
\hline Insight & $-16.0 \%$ & $-36.1 \%$ & $-10.4 \%$ & $-15.1 \%$ & $-12.8 \%$ \\
\hline Prius & $-3.5 \%$ & $-21.1 \%$ & $-1.7 \%$ & $-6.3 \%$ & $-4.0 \%$ \\
\hline
\end{tabular}




\section{COMPARING NEW FUEL ECONOMY TESTING RESULTS}

The AVTA's fuel economy testing results from the baseline performance (new vehicles) SAE J1634 testing with the AC on are either within the bounds of the EPA's city and highway results (Figure 18) or within $1 \mathrm{mpg}$ (the Civic is $+0.8 \mathrm{mpg}$ and the Accord is $-0.4 \mathrm{mpg}$ ). Given that the SAE J1634 drive cycle is a combination of city and highway driving, this would be anticipated. However, all of the AVTA's SAE J1634 AC-on test results are between 2 mpg (2 WD Silverado) and $13.3 \mathrm{mpg}$ (Insight) lower than the lowest respective EPA test result (both of the EPA tests are conducted with the AC off).

The AVTA fleet testing fuel economy results to date all fall within the AVTA's two (AC on and AC off) baseline performance SAE J1634 test results.
Two of the AVTA's fleet testing results are also within the EPA's city and highway results, the Silverado's 18.5 mpg falls within the EPA's 18 and $20 \mathrm{mpg}$ results, and the Lexus RX400h's $28.1 \mathrm{mpg}$ falls within the EPA's 24 and $30 \mathrm{mpg}$. The AVTA's Civic (-9.4 mpg and $-20 \%)$ and Insight (-11.8 mpg and $-21 \%)$ fleet testing results are the two HEVs that deviate the most from the EPA results.

\section{FUTURE HEV TESTING}

The Lexus RX400h and the Toyota Highlander HEVs will be baseline performance tested early 2006. Two Highlanders entered fleet testing during October 2005. As each HEV completes fleet testing at or close to 160,000 miles, they will undergo AC-on and AC-off endof-life SAE J1634 tests as well as the two battery tests.

As additional HEVs are introduced by original equipment manufacturers, they will enter baseline performance and fleet testing as funding allows.

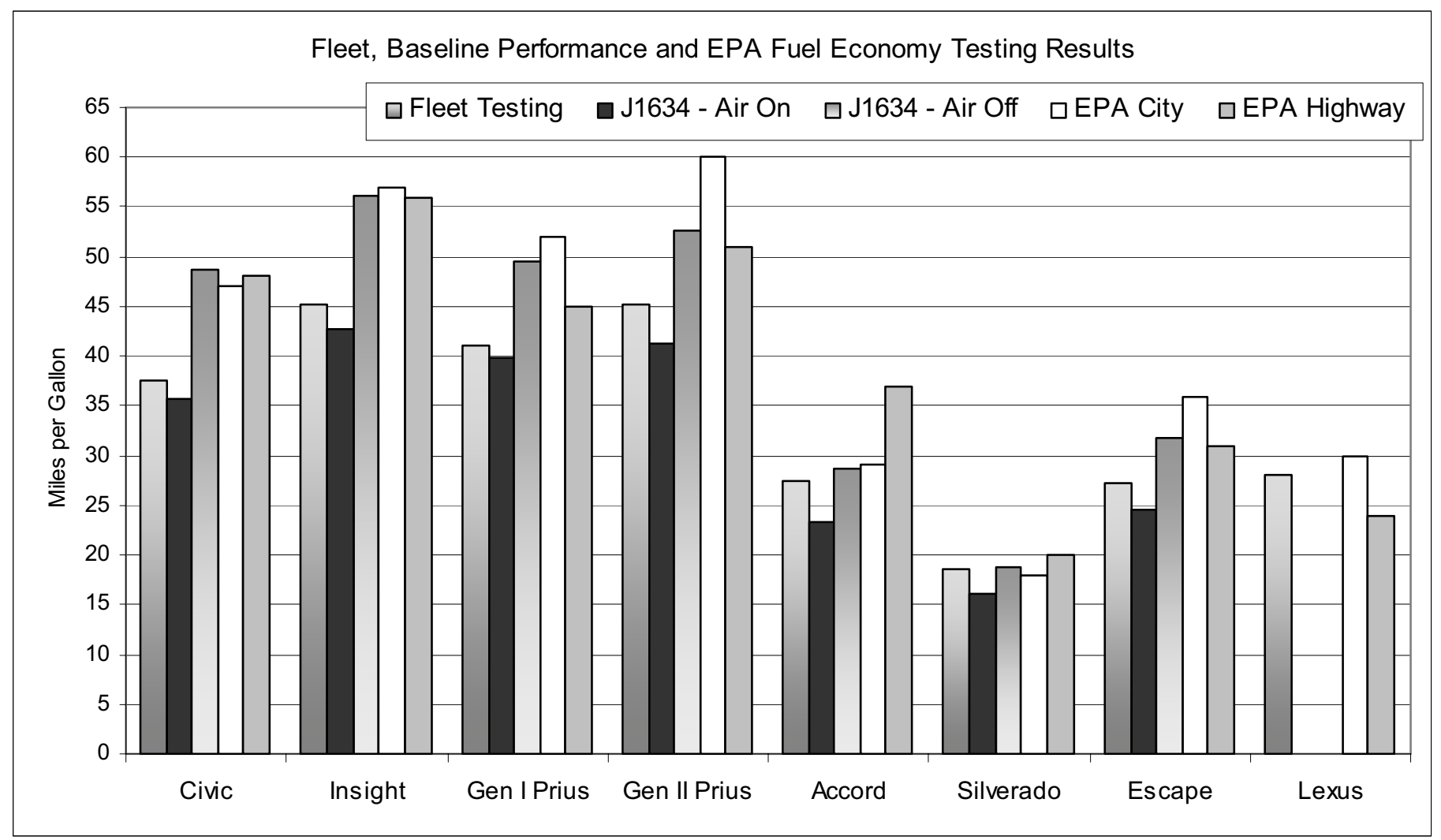

Figure 18. Fleet, baseline performance (SAE J1634 with the AC on and with AC off), and EPA city and highway fuel economy testing results.

\section{CONCLUSIONS}

- HEV performance (such as maximum speed and acceleration) is comparable to non-HEV internal combustion engine vehicles of similar vehicle classes. Some of the HEVs appear to be designed to maximize performance (Accord at 8.5 seconds for zero to $60 \mathrm{mph}$ ) and others fuel economy (Gen II Prius at $45.1 \mathrm{mpg}$ and Insight at $45.2 \mathrm{mpg}$ in fleet testing).
- The average HEV fuel economy results for the SAE $\mathrm{J} 1634$ tests with the AC on is $21 \%$ lower than with the AC off (31.9 mpg with the AC on and $40.9 \mathrm{mpg}$ with the $A C$ off). Depending on one's point of view, the average $\mathrm{AC}$-off results can also be stated as being $28 \%$ higher than the average $A C$-on results for the SAE J1634 testing.

- When comparing the capacity discharged during the AC on and off SAE J1634 testing, the seven HEVs had $21 \%$ more capacity discharged during the $A C$ 
on tests compared to the AC off tests; however, two of the seven had capacity discharge decreases of 28\% (Escape) and 6\% (Gen I Prius).

- There appears to be significant seasonal variations in fuel economy during fleet testing, with the earlier HEVs (Insights, Civics, and Gen I Prius) having an average decrease in $\mathrm{mpg}$ of $8.2 \%$ during the hottest three months compared to the coolest three months.

- The six high-mileage $(160,000$ miles $)$ Insights, Civics, and Gen I Prius (two of each) had average life-cycle costs of 21.5 cents per mile, while the 14 lower-mileage HEVs (same models, plus two Gen II Prius and two Silverado HEVs) had average lifecycle costs of 54.3 cents per mile. The difference in vehicle ownership costs (purchase minus sales prices) is on average 29.8 cents of this difference.

- HEV repair and maintenance cost rates appear to increase significantly as HEVs age. The highmileage HEVs have average maintenance and repair costs of 4.8 cents per mile compared to 1.9 cents per mile for the low-mileage HEVs

- The results for the end-of-life $(160,000$ miles) static battery testing suggest that the two Civics have remaining battery capacities of about $68 \%$ and the two Insights have remaining battery capacities of about $85 \%$. The two end-of-life Gen I Prius have remaining battery capacities of about $39 \%$.

- The end-of-life (160,000 miles) Phase I SAE J1634 fuel economy tests show increases in fuel economies in 11 of 12 tests (six with the $A C$ on and five with it off) for the six HEVs in end-of-life testing. Compared to a new Insight, one Insight had a small decrease $(1.2 \mathrm{mpg})$ during the SAE J1634 test with the AC off. The greatest increase was for a Gen I Prius at $3.2 \mathrm{mpg}$.

- The end-of-life (160,000 miles) Phase II SAE J1634 fuel economy tests show decreases in fuel economies in five of six tests (three with the AC on and three with it off) for the three HEVs in end-of-life Phase II testing. The Honda Insight had decreases of $4.9 \mathrm{mpg}$ with the $A C$ on and $6.2 \mathrm{mpg}$ with the $A C$ off, the Honda Civic had decreases of $1.5 \mathrm{mpg}$ with and without $A C$, and the Gen I Prius had an increase of $1.2 \mathrm{mpg}$ without $A C$ and a decrease of $2.0 \mathrm{mpg}$ with AC. These findings do not indicate any appreciable fuel economy loss with the exception of the Honda Insight, which demonstrated a slight decrease even when considering the use of different drivers between baseline and Phase II testing.

- Although SAE J1634 testing was performed with a relatively small sample size, the data demonstrated no distinct correlation between battery degradation (reduction in battery capacity) and fuel economy loss (reduction in fuel economy). The data indicated that the power demand on the batteries had increased, their capacity (to hold charge) had diminished, and yet fuel economy degradation was not directly proportional to either of these factors.

- All of the AVTA's SAE J1634 baseline performance test results with the AC off either fall in between or within no more than $1 \mathrm{mpg}$ outside of the EPA's city and highway mpg test results. With the AC on, all of the SAE J1634 mpg results are 2 to $13.3 \mathrm{mpg}$ below the EPA's lowest mpg results.

- To date, after 1.4 million miles, the fleet testing mpg results for the seven HEV models (that have also been baseline performance tested) are all within the two sets (AC on and off) of the AVTA's baseline performance (new vehicles) SAE J1634 mpg results. The fleet testing mpg results for the Silverado and $\mathrm{RX} 400 \mathrm{~h}$ are also within the EPA city and highway mpg results. Given that the HEVs in fleet testing are driven with and without the $A C$ on, it would appear that the AVTA's AC-on and AC-off SAE J1634 tests are accurate predictors of real-world HEV fuel economy.

- Consideration will be given to performing end-of-life coast-down testing and using the derived coefficients for end-of-life SAE J1634 testing.

\section{REFERENCES}

1. The HEV specifications and testing procedures can be found at http://avt.inel.gov/hev.shtml

2. J.E. Francfort, N. Nguyen, J. Phung, J. Smith, and M. Wehrey. Honda Insight Hybrid Electric Vehicle Performance Characterization Report. INEEL02/00102. Idaho National Engineering and Environmental Laboratory. Idaho Falls, Idaho. March 2002.

3. J.E. Francfort, N. Nguyen, J. Phung, J. Smith, and M. Wehrey. Toyota Prius Hybrid Electric Vehicle Performance Characterization Report. INEEL02/01522. Idaho National Engineering and Environmental Laboratory. Idaho Falls, Idaho. December 2001.

4. Fleet Test And Evaluation Procedure. Electric Transportation Applications. ETA-FEP 001. Effective June 30, 2004.

5. All of the AVTA HEV results, reports, and fact sheets can be found at http://avt.inel.gov/hev.shtml

6. FreedomCAR Battery Test Manual For Power-Assist Hybrid Electric Vehicles. DOE/ID-11069. Idaho 
National Engineering and Environmental Laboratory. Draft. April 2003.

7. Hybrid Electric Vehicle Battery End-of-Life Testing. ETA-HTP14. Electric Transportation Applications. August 1, 2005.

8. Implementation of SAE Standard J1263 - Road Load Measurement and Dynamometer Simulation Using Coast Down Techniques. ETA-HTP01. November 1, 2004. Electric Transportation Applications.

\section{CONTACT}

James Francfort James.francfort@inl.gov

http://avt.inl.gov

INL/CON-05-00415 